\title{
Intensitas Penggunaan Media Android Hubungannya dengan Minat Belajar Peserta Didik
}

\author{
Abdurrohman \\ Universitas Islam Negeri (UIN) Sultan Maulana Hasanuddin Banten \\ Email: abdurrohman1908@gmail.com \\ Hasbullah \\ Universitas Islam Negeri (UIN) Sultan Maulana Hasanuddin Banten \\ Email: hasbullah@uinbanten.ac.id \\ Juhji \\ Universitas Islam Negeri (UIN) Sultan Maulana Hasanuddin Banten \\ Email: juhji@uinbanten.ac.id
}

Received: January 29, 2020 | Accepted: June 10, 2020

\begin{abstract}
This study aims to examine whether there is a relationship between the intensity of the use of Android media with the learning interest of students in Islamic Religious Education subjects. The study was conducted at State High School 3 Serang City, Banten Province. The research method uses correlational analysis. The study sample was taken as many as 40 (forty) students who are still actively learning in the current school year. Research data were collected through a validated questionnaire. The data were analyzed using Pearson's correlation techniques through the help of the SPSS version 16.00 application. The results showed a weak positive relationship between the intensity of the use of Android media with the interest in learning of students in Islamic Religious Education subjects. Thus, students' interest in learning is largely influenced by other factors outside the variables of this study.
\end{abstract}

\begin{abstract}
Abstrak
Penelitian ini bertujuan untuk menguji apakah ada hubungan antara intensitas penggunaan media Android dengan minat belajar peserta didik pada mata pelajaran Pendidikan Agama Islam. Studi dilakukan di Sekolah Menengah Atas Negeri 3 Kota Serang Provinsi Banten. Metode penelitian menggunakan analisis korelasional. Sampel penelitian diambil sebanyak 40 (empat puluh) peserta didik yang masih aktif belajar pada tahun pelajaran berjalan. Data penelitian dikumpulkan melalui angket yang sudah divalidasi. Data dianalisis menggunakan teknik korelasional Pearson melalui bantuan aplikasi SPSS versi
\end{abstract}


16.00. Hasil penelitian menunjukkan adanya hubungan positif yang lemah antara intensitas penggunaan media Android dengan minat belajar peserta didik pada mata pelajaran Pendidikan Agama Islam. Dengan demikian, minat belajar peserta didik sebagian besar dipengaruhi oleh faktor-faktor lain di luar variabel penelitian ini.

\section{Keywords}

Interest, learning, Android, media

\section{Pendahuluan}

Pembelajaran merupakan suatu kegiatan yang melibatkan peserta didik (Baharun, 2015) dan pendidik serta lingkungannya dalam upaya untuk memperoleh pengetahuan, keterampilan, dan nilai-nilai positif dengan memanfaatkan berbagai media dan sumber belajar untuk mencapai suatu tujuan yang diharapkan (Juhji \& Nuangchalerm, 2020). Suprihatin (2015) menyatakan bahwa pembelajaran adalah upaya membelajarkan peserta didik untuk belajar. Kegiatan pembelajaran akan melibatkan siswa mempelajari sesuatu dengan cara efektif dan efisien. Efektivitas dan efisiensi kegiatan pembelajaran dapat dilihat dari aspek peserta didik dan guru (Adrian \& Erliani, 2018; Surani \& Mifthahudin, 2018). Pelibatan guru dalam pembelajaran sangat penting karena guru merupakan ujung tombak keberhasilan suatu bangsa (Taleb, 2013), karena guru yang kreatif, inovatif, dan cerdas akan menghasilkan generasi yang unggul di masa depan.

Perkembangan media baik dari segi teknologi dan komunikasi sudah sedemikian cepat (Ameliola \& Nugraha, 2013), sehingga tanpa disadari sudah mempengaruhi setiap aspek kehidupan manusia. Produk teknologi dan komunikasi sudah menjadi kebutuhan sehari-hari (Prayogo et al., 2015; Juhji, 2019) dalam menjalankan aktivitas segala kehidupan. Pemanfaatan teknologi dan komunikasi dalam dunia pendidikan diharapkan mampu memberikan dampak yang positif dan dapat menciptakan suasana belajar yang menarik bagi pendidik dan peserta didik. Perkembangan teknologi dan komunikasi mampu mempengaruhi proses pembelajaran yang efektif dan selanjutnya berdampak pada upaya bagaimana seorang pendidik mampu mengidentifikasi, memilih dan menetapkan sebuah media dalam pembelajaran dengan tepat ketika proses belajar mengajar berlangsung, seorang guru dituntut untuk menggunakan berbagai strategi (Hasbullah et al., 2019) dan media pembelajaran yang bervariasi, agar pembelajaran tidak monoton dan membosankan (Juhji, 2019).

Media mempunyai keunggulan membantu para pendidik dalam menyampaikan materi atau pesan pembelajaran lebih cepat dan lebih mudah ditangkap oleh para peserta didik (Baharun, 2016). Media pembelajaran adalah 
suatu teknologi pembawa pesan yang dapat digunakan untuk keperluan pembelajaran. Kehadiran media pembelajaran dapat memberikan dorongan minat belajar peserta didik, karena berbagai jenis komponen dalam lingkungan peserta didik yang dapat memberikan rangsangan untuk belajar. Laporan hasil penelitian Siagian (2012) menyatakan adanya pengaruh minat belajar terhadap prestasi belajar peserta didik. Gusniwati (2015) juga melaporkan adanya pengaruh langsung minat belajar terhadap penguasaan konsep. Ini menunjukkan semakin tinggi minat belajar peserta didik semakin tinggi pula prestasi dan penguasaan konsep peserta didik. Oleh karena itu, peningkatan minat belajar peserta didik harus selalu terus diupayakan.

Menurut Priasa (2015), minat merupakan terminologi aspek kepribadian yang menggambarkan adanya kemauan yang timbul dari dalam diri individu untuk memilih objek lain yang sejenis. Minat juga diartikan sebagai kecenderungan dan kegairahan yang tinggi atau keinginan yang besar seseorang terhadap sesuatu (Kamarudin, 2015). Menurut Olivia (2011) minat belajar adalah sikap ketaatan pada kegiatan belajar, baik menyangkut perencanaan jadwal belajar maupun inisiatif melakukan usaha secara sungguh-sungguh. Sedangkan Priasa (2015) melaporkan bahwa minat belajar adalah suatu keinginan atas kemauan yang disertai perhatian dan keaktifan yang disengaja yang akhirnya melahirkan rasa senang dalam perubahan tingkah laku, baik berupa pengetahuan, sikap, dan keterampilan. Minat belajar dapat diukur melalui 4 (empat) indikator sebagaimana yang disebutkan oleh (Slameto, 2010) yaitu ketertarikan untuk belajar, perhatian dalam belajar, motivasi belajar, dan pengetahuan.

Faktor-faktor yang mempengaruhi rendahnya minat belajar peserta didik banyak diteliti oleh peneliti sebelumnya. Faktor-faktor tersebut diantaranya adalah faktor intern (dalam diri siswa) yang meliputi (1) kondisi siswa, (2) kemampuan intelektual, (3) motivasi, dan (4) kebiasaan belajar siswa. Sedangkan faktor ekstern (dari luar diri siswa) meliputi: (1) lingkungan, (2) motivasi, (3) kondisi guru, (4) keluarga atau orang tua, serta (5) keadaan ekonomi (Amali, 2013). Dari faktor-faktor yang diungkapkan, terlihat adanya faktor ekstern yaitu guru yang mempengaruhi minat belajar peserta didik. Bagaimana guru mampu menggunakan media pembelajaran secara aktif dan kreatif menjadikan pertanyaan dalam upaya meningkatkan minat belajar peserta didik.

Penggunaan media secara kreatif akan memperbesar minat belajar belajar peserta didik dalam proses kegiatan belajar mengajar. Sehubungan dengan peran media yang sangat diperlukan oleh seorang pendidik dalam proses kegiatan belajar mengajar, maka dalam perkembangan zaman yang serba canggih saat ini media berbasis Android dapat digunakan oleh pendidik sebagai 
alternatif dalam memberikan bahan ajar pada proses pembelajaran yang dilakukan di luar kelas. Berdasarkan uraian tersebut, perlu dilakukan penelitian terkait peningkatan minat belajar peserta didik. Oleh karena itu, penelitian ini bertujuan untuk mengetahui apakah ada hubungan antara intensitas penggunaan media Android dengan minat belajar peserta didik.

\section{Metode}

Metode yang digunakan pada penelitian ini adalah metode korelasional yang bertujuan untuk mencari bukti berdasarkan data yang ada untuk menjawab pertanyaan apakah hubungan antara variabel intensitas penggunaan media Android dan minat belajar siswa itu termasuk hubungan yang kuat, cukup, atau lemah. Populasi dalam penelitian ini adalah siswa SMA Negeri 3 Kota Serang Provinsi Banten yang berjumlah 161 siswa. Sedangkan sampel penelitian sejumlah 40 orang siswa yang didasarkan pada pendapatnya Arikunto (2013) yang menyatakan bahwa apabila subjeknya kurang dari 100, lebih baik diambil semuanya sehingga penelitiannya merupakan penelitian populasi dan jika subjeknya lebih dari 100 dapat diambil antara $10 \%-15 \%$ atau 20\%-25\% lebih. Instrumen yang digunakan pada penelitian ini adalah kuisioner (angket) sejumlah 30 butir. Analisis data menggunakan korelasi product moment menggunakan bantuan aplikasi SPSS 16.00.

\section{Hasil}

\section{Analisis Deskriptif}

Data hasil penelitian kedua variabel (variabel intensitas penggunaan media Androdi sebagai variabel bebas dan variabel minat belajar siswa sebagai variabel terikat) dianalisis melalui bantuan aplikasi SPSS versi 16.00, dan hasilnya dapat dilihat pada tabel 1 di bawah ini.

Tabel 1. Statistik deskripstif intensitas penggunaan media Android

\begin{tabular}{|c|c|c|c|c|c|c|}
\hline & $\mathrm{N}$ & Minimum & Maximum & Mean & $\begin{array}{c}\text { Std. } \\
\text { Deviation }\end{array}$ & Variance \\
\hline $\begin{array}{l}\text { Intensitas Penggunaan } \\
\text { Media Android }\end{array}$ & 40 & 70 & 91 & 83.05 & 4.997 & 24.972 \\
\hline Minat Belajar Siswa & 40 & 74 & 102 & 83.78 & 5.677 & 32.230 \\
\hline Valid N (listwise) & 40 & & & & & \\
\hline
\end{tabular}


Berdasarkan data pada tabel 1 di atas, diperoleh data intensitas penggunaan media Android dengan nilai minimum sebesar 70, nilai maksimum sebesar 91, rata-rata sebesar 83.05, standar deviasi sebesar 4.997, dan varians sebesar 24.972. Sedangkan data minat belajar siswa diperoleh nilai minimum sebesar 74 , nilai maksimum sebesar 102 , rata-rata sebesar 83.78 , standar deviasi sebesar 5.677, dan varians sebesar 32.230.

\section{Uji Prasyarat}

Data kedua variabel yang telah dikumpulkan selanjutnya diuji prasyarat analisis, yang meliputi uji normalitas dan uji linieritas. Hasil pengujian normalitas menggunakan uji Liliefors diperoleh hasil bahwa seluruh variable berdistribusi normal. Hasil pengujian linieritas menggunakan ANOVA diperoleh hasil bahwa persamaan regresi yang terbentuk antara kedua variabel adalah linier, sehingga dapat dilanjutkan menggunakan statistik parametrik, dengan korelasi Product Moment.

\section{Uji Hipotesis}

Hipotesis yang diajukan dalam penelitian ini adalah: "ada hubungan positif antara intensitas penggunaan media Android dengan minat belajar siswa pada mata pelajaran PAI". Analisis korelasi terhadap kedua variabel (variabel intensitas penggunaan media Android $=\mathrm{X}$ dan variabel minat belajar siswa $=\mathrm{Y}$ ) dilakukan melalui bantuan aplikasi software SPSS versi 16.00, dan dapat dilihat pada tabel 2 berikut ini.

Tabel 2. Uji korelasi

\begin{tabular}{llrr}
\hline & & $\begin{array}{c}\text { Intensitas Penggunaan } \\
\text { Media Android }\end{array}$ & $\begin{array}{c}\text { Minat Belajar } \\
\text { Siswa }\end{array}$ \\
\hline $\begin{array}{l}\text { Intensitas Penggunaan } \\
\text { Media Android }\end{array}$ & Pearson Correlation & 1 & $.443^{* *}$ \\
& Sig. (2-tailed) & 40 & .004 \\
Minat Belajar Siswa & $\mathrm{N}$ & $.443^{* *}$ & 40 \\
& Pearson Correlation & .004 & 1 \\
& Sig. (2-tailed) & 40 & 40 \\
\hline
\end{tabular}

**. Correlation is significant at the 0.01 level (2-tailed).

Berdasarkan data hasil analisis di atas, diketahui bahwa nilai korelasi sebesar 0.443 (lihat tanda bintang). Uji Korelasi (R) antara X (intensitas penggunaan media Android) terhadap Y (minat belajar siswa pada mata pelajaran PAI) $\mathrm{R}_{\mathrm{xy}}=0,443$ dengan koefisien determinasi (R2) $\mathrm{KD}=19,62 \%$. 
Selanjutnya untuk mengetahui keberartian korelasi ganda (R) dihitung dengan uji $\mathrm{F}=9,293$ dengan $\mathrm{F}_{\text {tabel }}=4.085$ sehingga koefisien korelasi secara bersamasama antara intensitas penggunaan media Android (X) dengan minat belajar siswa pada mata pelajaran PAI (Y) sebesar 9,293 tergolong lemah. Tingkat keberartian koefisien korelasi diuji dengan uji $\mathrm{F}$ diperoleh $\mathrm{F}$ hitung $=9,293$ > $\mathrm{F}_{\text {tabel }}=4.085$, maka terdapat korelasi (hubungan) yang signifikan antara intensitas penggunaan media Android terhadap minat belajar siswa pada mata pelajaran PAI. Artinya, penelitian ini dapat membuktikan bahwa ada hubungan positif antara intensitas penggunaan media Android denan variabel minat belajar siswa. Dengan demikian, penelitian mampu menjawab pertanyaan penelitian yang telah diajukan.

\section{Pembahasan}

Hasil penelitian digunakan untuk menjawab pertanyaan penelitian: "apakah ada hubungan antara intensitas penggunaan media Android dengan minat belajar peserta didik pada mata pelajaran Pendidikan Agama Islam?" Pengolahan data mengunakan analisis korelasional sederhana. Hasil penelitian menunjukkan adanya korelasi antar variabel berjalan satu arah, artinya semakin tinggi intensitas penggunaan media Android maka semakin tinggi pula minat belajar peserta didik, begitu pula sebaliknya. Sehingga jika intensitas penggunaan media Android mengalami penurunan makan minat belajar peserta didik pada mata pelajaran Pendidikan Agama Islam akan mengalami penurunan. Perhitungan koefisien korelasi berada pada kategori lemah/cukup dari intensitas penggunaan media Android terhadap minat belajar peserta didik pada mata pelajaran Pendidikan Agama Islam.

Untuk melihat seberapa besar hubungan intensitas penggunaan media Android dengan minat belajar peserta didik pada mata pelajaran Pendidikan Agama Islam dapat dilihat melalui nilai koefisien determinasi. Nilai koefisien determinasi dalam penelitian ini diperoleh dengan menghitung kuadrat dari nilai koefisien korelasi dikali 100\%, sehingga nilai koefisien determinasi yang didapat adalah 19,62\%. Arti dari nilai koefisien determinasi ini adalah bahwa minat belajar peserta didik pada mata pelajaran Pendidikan Agama Islam dipengaruhi oleh intensitas penggunaan media Android sebesar 19,62\%, sisanya $80,38 \%$ dipengaruhi oleh faktor-faktor lain yang tidak diteliti dalam penelitian ini, seperti: faktor intern (dalam diri peserta didik) yang meliputi (1) kondisi siswa, (2) kemampuan intelektual, (3) motivasi, dan (4) kebiasaan belajar siswa; dan faktor ekstern (dari luar peserta didik) yang meliputi: (1) lingkungan, (2) motivasi, (3) kondisi guru, (4) keluarga atau orang tua, serta (5) keadaan ekonomi (Amali, 2013). Oleh karena itu, perlu penelitian lebih 
lanjut dengan variabel yang lebih banyak di luar variabel intensitas penggunaan media Android.

Secara keseluruhan, hasil penelitian ini mampu menjawab pertanyaan penelitian sehingga disimpulkan bahwa intensitas penggunaan media Android memiliki hubungan yang cukup dengan minat belajar peserta didik pada mata pelajaran Pendidikan Agama Islam. Peningkatan minat belajar peserta didik akan mempengaruhi prestasi belajar mereka. Sebagaimana disampaikan oleh Siagian (2012) dan Gusniwati (2015) bahwa minat belajar peserta didik dapat mempengaruhi prestasi belajar dan penguasaan konsep peserta didik. Semakin tinggi minat belajar peserta didik semakin tinggi pula prestasi dan penguasaan konsep peserta didik. Oleh karena itu, peningkatan minat belajar peserta didik harus selalu terus diupayakan

\section{Kesimpulan}

Perkembangan media baik dari segi teknologi dan komunikasi sudah sedemikian cepat sehingga tanpa disadari sudah mempengaruhi setiap aspek kehidupan manusia. Termasuk di dalamnya adalah media Android. Penggunaan media Android sudah menjadi kebutuhan pokok di segala lapisan lini masyarakat, termasuk juga para peserta didik. Pemanfaatan media Android mempengaruhi minat belajar peserta didik. Hasil studi menunjukkan adanya hubungan positif yang lemah antara intensitas penggunaan media Android dengan minat belajar peserta didik pada mata pelajaran Pendidikan Agama Islam. Dengan demikian, minat belajar peserta didik sebagian besar dipengaruhi oleh faktor-faktor lain di luar variabel penelitian ini.

\section{DAFTAR PUSTAKA}

Adrian, Y., \& Erliani, S. (2018). Efektivitas model pembelajaran kooperatif stad terhadap hasil belajar kognitif dan daya retensi siswa kelas v sekolah dasar. Muallimuna: Jurnal Madrasah Ibtidaiyah, 4(1), 1-10.

Amali, F. (2013). Faktor-faktor Yang Mempengaruhi Rendahnya Minat Belajar Siswa pada mata pelajaran IPS Di Kelas V SDN IV Telaga Kabupaten Gorontalo [Skripsi]. Universitas Negeri Gorontalo.

Ameliola, S., \& Nugraha, H. D. (2013). Perkembangan media informasi dan teknologi terhadap anak dalam era globalisasi. International Conference on Indonesian Studies" Ethnicity and Globalization".

Arikunto, S. (2013). Prosedur Penelitian Suatu Pendekatan Praktik. Rineka Cipta. 
Baharun, H. (2015). Penerapan pembelajaran active learning untuk meningkatkan hasil belajar siswa di madrasah. PEDAGOGIK: Jurnal Pendidikan, 1(1).

Baharun, H. (2016). Pengembangan media pembelajaran pai berbasis lingkungan melalui model assure. Cendekia, 14(2), 231-246.

Gusniwati, M. (2015). Pengaruh Kecerdasan Emosional dan Minat Belajar terhadap Penguasaan Konsep Matematika Siswa SMAN di Kecamatan Kebon Jeruk. Formatif: Jurnal Ilmiah Pendidikan MIPA, 5(1). https://doi.org/10.30998/formatif.v5i1.165

Hasbullah, H., Juhji, J., \& Ali, M. (2019). Strategi belajar mengajar dalam upaya peningkatan hasil belajar pendidikan agama islam. Edureligia, $3(1), 17-24$.

Juhji, J. (2019). Analyzing Madrasah Ibtidaiyah Teacher Candidates Skill of Technological Pedagogical Content Knowledge on Natural Science Learning. Al Ibtida: Jurnal Pendidikan Guru MI, 6(1), 1-18. http://dx.doi.org/ 10.24235/al.ibtida.snj.v6i1.3658

Juhji, J., \& Nuangchalerm, P. (2020). Interaction between Science Process Skills and Scientific Attitudes of Students towards Technological Pedagogical Content Knowledge. Journal for the Education of Gifted Young Scientists, 8(1), 1-16. http://dx.doi.org/10.17478/jegys.2020.XX

Kamarudin, A. (2015). Pembelajaran Perspektif Islam. Remaja Rosdakarya.

Olivia, F. (2011). Teknik Ujian Efektif. PT. Elex Media Komputindo.

Prayogo, S. S., Saptariani, T., \& Salahuddin, N. S. (2015). Rancang Aplikasi Android Pengendali Mobil dan Kamera Menggunakan APP Inventor. Seminar Nasional Aplikasi Teknologi Informasi (SNATI), 1, 1.

Priasa, D. J. (2015). Manajemen Peserta Didik dan Model Pembelajaran. Alfabeta.

Siagian, R. E. F. (2012). Pengaruh minat dan kebiasaan belajar siswa terrhadap prestasi belajar matematika. Formatif: Jurnal Ilmiah Pendidikan MIPA, 2(2), 122-131.

Slameto, S. (2010). Belajar dan Faktor-faktor yang Mempengarubinya (5th ed.). Rineka Cipta.

Suprihatin, S. (2015). Upaya guru dalam meningkatkan motivasi belajar siswa. Jurnal Pendidikan Ekonomi UM Metro, 3(1), 73-82.

Surani, D., \& Mifthahudin, M. (2018). Kompetensi Guru dan Motivasi Mengajar Guru Berpengaruh terhadap Efektivitas Pembelajaran di SMK Negeri 3 Kota Serang. Tarbawi: Jurnal Keilmuan Manajemen Pendidikan, 4(02), 149-158. https://doi.org/doi:10.32678/tarbawi.v4i02.1227 
Taleb, T. F. (2013). Job satisfaction among Jordan's kindergarten teachers: Effects of workplace conditions and demographic characteristics. Early Childhood Education Journal, 41(2), 143-152. 
